\title{
Medical Hallyu In Mongolia: A Case Study Of Dr. Kwan-Tae Park's Spirituality And Medical Service
}

\author{
HO-WOOG KIM ${ }^{1}$, IN-SEOK SEO ${ }^{2}$, MOO-JIN JEONG ${ }^{3}$, JUN-KI CHUNG ${ }^{4 *}$ \\ ${ }_{1,2,3,4}$ Kwangshin University, Gwangju City, South Korea, \\ ${ }^{1}$ Ph.D., Assistant Professor of Historical Theology, Kwangshin University. \\ ${ }^{2}$ Ph.D., Adjunct Professor of History of Christianity, Department of Church History, Kwangshin University. \\ ${ }^{3}$ Ph.D., teaches "History of Christian Thought," Department of Church History, Kwangshin University. \\ 4*former Vice President and Dean of Graduate School at Kwangshin University, studied at both University of Chicago (Ph.D. and \\ post-doctorate) and Trinity Evangelical Divinity School (D.Min. in Missiology). Currently he is serving as Senior Researcher at \\ Institute for Pietatis Theologia, Kwangshin University. He is also serves as a reviewer of SCI journal articles published in the US.
}

\begin{abstract}
:
Since the establishment of diplomatic relations between South Korea and Mongolia in 1990, Hallyu (the Korean Wave) has rapidly spread to Mongolia. Korean food and medicine, as well as Korean drama and pop music, are welcomed by Mongolians. The purpose of this study is to examine the influence of Korean medical service on Mongolia, focusing on the Korean medical missionary Kwan-tae Park. We will show that his excellent human relationship as a reason for his fruit-bearing ministry in the Mongolian society, which is somewhat unfriendly to aggressive Christian evangelism. In conclusion, we will argue that his ministry is imitating Jesus' life presented by the New Testament in a large framework.
\end{abstract}

Keywords:

ACH, Evangelism, Medical, Mongolia, Park, South Korea

Article Received: 18 October 2020, Revised: 3 November 2020, Accepted: 24 December 2020

\section{INTRODUCTION}

In Mongolian society, Hallyu is expanding into various areas, beginning with K-drama, K-movie, $\mathrm{K}$-pop, and K-food. Four years after diplomatic relations between South Korea and Mongolia, Kmedicine also started with the establishment of Yonsei Friendship Hospital in 1994. Subsequently, in 2001, 'Mobio' was built in Ulaanbaatar, Mongolia with the aim of intensively diagnosing patients with cardiovascular, gastrointestinal, and liver diseases (Delgermurun, 2007). In the same year, the Korea International Cooperation Agency (KOICA) founded an oriental medical hospital, treating more than 200 Mongolian patients a day. Songdo Hospital was opened in 2007 and is operating well. The Korean medical institutions in Mongolia are not only caring for patients, but have hosted various seminars inviting professional medical staff from South Korea. Through this training, Mongolian medical staff are informed of the trends and practices of current medical research. Furthermore, many Korean physicians are dedicated to teaching at the Mongolian National Medical University (MNMU) by training medical students who will be responsible for Mongolia's future medical ministry.

Historically, the influential Dr. Tae-jun Lee (1883-1921) widely spread Korean medicine to Mongolia and has been called the "Schweitzer of Mongolia" (Son, 2020). Dr. Lee entered Mongolia in 1914 after studying medicine at Severance Medical School in Korea during the period of Japanese invasion of Korea (1910-1945). He worked as a physician for Bogd Khan (c. 18691924), the last monarch of Mongolia. At that time, over $50 \%$ of Mongolians were infected with syphilis, which was regarded as a curse, and Mongolian people were horrified (Ha, 2019). Dr. Lee quickly achieved great success by injecting the German medicine Salvaric acid. In July 1919, the 
monarch, impressed by Dr. Lee's efforts, awarded Lee the highest medal of Mongolia, "Erdenine Ochir," which means "a shining diamond." Dr. Lee was deeply respected as a precious person shining like a diamond in the lives of Mongolians. Upon his death, the Mongolian government built his memorial park in front of the Zaisan Memorial in honor of his dedication. Almost all Korean medical doctors in Mongolia are 'spiritual' descendants of Dr. Lee. This is because these people have not come to Mongolia to obtain their own honor or financial benefits, but rather to treat the Mongolians, giving them a better, healthier life. This study attempts to examine the true nature of the medical Hallyu in Mongolia by illuminating the life and ministry of Dr. Gwan-tae Park, one of many Korean medical professionals.

While Dr. Lee has received respect and adoration for being called "Mongolia's Schweitzer" or "Precious Diamond," Dr. Park has been called "God's Hand" or "Golden Hand." He is the first in Mongolia to perform laparoscopic surgery and is recognized as the father of laparoscopic treatment. Dr. Park was able to live a good and meaningful life in South Korea as a leader in the Korean medical field (Kim, 2020). He gave up all his fame and entered Mongolia where the medical environment was not well developed. This study will explore his motives for making this decision, his influence in Mongolia, and the Christian faith that dominates his life. In addition, this study will show that his Christian ministry, which has adopted a personal and relational method instead of artificial and mechanical management, produces very positive results. Finally, we will argue that Park's lifeevangelist, teacher, and physician - has imitated the life of Jesus in the New Testament (NT) in many aspects.

\section{BIOGRAPHICAL INFORMATION}

Kwan-tae Park was born in a rural area of Gyeongsang Province in 1970 in South Korea. In February 1988 as a senior in high school, he attended a revival meeting and received Christ as his personal savior (Park 2017b). It is difficult to explain his religious experience theoretically, but what is certain is that Park has found the most reliable object of faith in his life. Now Jesus has become the object of devotion to his whole life. His family members were all devout Buddhists, and he alone became a Christian. Park made a vow that if his God allowed him to study at a good medical school, he would go out as a medical missionary to repay God's grace. From the time he attended the medical school of Korea University, he has been working hard in voluntary medical services in Korea and abroad. His close Christian friends of the medical school were Jae-hak Shim and Soo-kyung Jeong, who later became his wife. Park majored in a variety of surgical fields during his bachelor's, master's, and doctoral studies at Korea University. Surgery was a hard field that medical students avoided as a major due to many difficult tasks such as various operations, but Park chose surgery with joy because he thought that it could help more patients in the mission field.

Park served four years (2001-2005) as a medical missionary in Mongolia, working with KOICA and returned to Korea to begin his work as a surgeon and clinical assistant professor at Asan Medical Center in Seoul (2005-2008). From 2009 to 2013 he served as a professor of transplant and vascular surgery at Korea University's Anam Hospital. In 2014, he left all the positions of an honorable and promising Korean doctor and returned to Mongolia as a medical missionary with his wife, a gynecologist. Currently, Park is serving as a professor of surgery at MNMU and as Director of Agape Christian Hospital (ACH) in Mongolia. The Korean government, which appreciated his dedication, awarded the Minister of Health and Welfare commendation in 2010 and the Prime Minister's Award for Overseas Service in 2016. In Mongolia, he has also won several awards, including the Ulaanbaatar Mayor's Medal and the Mongolian Prime Minister's Commendation (Kim 
2020). Park and his wife have two daughters, the eldest is married and lives in Korea.

\section{REASONS FOR CHOOSING MONGOLIA A}

\section{S A MISSION FIELD}

In 1999, Park joined the short-term mission team for medical service to Mongolia and treated many Mongolians. During this service, he expected some deep spiritual experience in his heart, but nothing happened. Yet on the last night of his stay, he saw the stars in the sky on the Mongolian grasslands as if they were the faces of the suffering Mongolians he had treated. And he thought he could be a useful person for them. However, the motive of Park's decisive decision to devote his life to Mongolia was the will of his close friend, Jae-hak Shim. At one time, Park and Shim talked about going to Mongolia as missionaries. They discussed that in Mongolia, if Park was in charge of surgery and Shim in charge of internal medicine, how wonderful it would be to cooperate with each other. However, Shim died of blood cancer before he was able to realize his dream. Shortly before his death, he called Park and asked him to conduct missionary work in Mongolia for his part. Shim's request was so 'holy' that Park found himself unable to refuse it. Shim's will has served both a duty and a source of inspiration for Park to do mission work in Mongolia (Park, 2017b). In 2001, as the Korean government tried to support Mongolia through KOICA, Park was able to go to Mongolia as a member of KOICA.

\section{PARK'S FIRST MISSION TO MONGOLIA (2001-2005)}

Park devotedly treated Mongolians for four years. During this period, he mainly devoted himself to being the head of surgery at 'Yonsei Friendship Hospital' in Mongolia and visiting professor at MNMU (UBACH, 2021). Founded in 1942, MNMU is currently the only national medical school in Mongolia. It has its own educational hospital to provide students with medical theory and practice. Park said that pride as a medical professor is disciple-making. Just as 3\% salt squeezes the water out of the entire sea, many Mongolian patients can get help if these medical students are disciplined and sent to all over Mongolia. Park trained medical students during the four-year period by performing more than 3,000 surgeries. Meanwhile, he sent many Mongolian medical students to South Korea to study the Korean medical system for three months.

Park also served as a lay pastor for three years in a local Mongolian church where a Korean missionary was away (Park, 2017b). He memorized all the sermon texts in Mongolian to deliver the messages two to three times a week. He confessed that memorizing the messages in Mongolian was the best way to learn Mongolian. He conducted baptismal ceremony in a river where water flows naturally. The celebration of baptism in unpolluted nature left an indescribable impression on him.

Park often visited remote Mongolia to treat his patients. For example, from 2002 to the present, near Hovsgol, the largest lake in Mongolia, he is engaging in a ministry of the Tssatan tribe, which is an ethnic minority in Mongolia with Eskimo-like roots, and is characterized by living with reindeers. Reindeers are not only the best mode of transportation for the nomadic Tssatan, but also an important food source of energy to endure harsh winters. To get there from Ulaanbaatar, it takes about 20 hours by car. After getting out of the car and riding reindeers or horses for about 10 hours, Park meet the Tssatan people living in the mountains. At first, Park treated them who had never seen a doctor in their lives, performing laparoscopic surgery. Park was the first physician to practice the laparoscopic surgery in Mongolia. It is a surgical method in which a small hole of $0.5 \sim 1.5 \mathrm{~cm}$ in size is made in the abdomen and various medical devices are inserted into it. Compared with traditional open surgery, this surgery has the advantage that the surgical wound is cosmetically pleasing, because the size of the incision is smaller, the pain caused by the wound is 
much smaller, and the patient's recovery speed is faster. His operation has been performed in a triangular tent called Ortz, where they live, and local people flock around the tent to watch his treatment. When the patients are healed, some Tssatan people consider Park as a god, calling him "Hand of God" or "Golden Hand."

\section{PARK'S SECOND MISSION TO MONGOLI} A (2014-present)

\section{The Long-term Missionary Decision}

There were four important reasons for Park to rekindle his great interest in long-term missions in Mongolia. For one, the will of his old friend Shim was always lingering in his mind. The second was his wife, Dr. Jeong, who was anxious that her husband would be satisfied with life in Korea and less interested in missions. Even after returning to Korea, she continued to have a deep affection and interest in Mongolian missions. She did not think it was God's will to live comfortably in Korea under the pretext of realistic problems such as future problems and children's education after her husband retired as a professor. The third reason was that Korea University had to temporarily dispatch a doctor to Mongolia, and Park was recommended to go because he was more familiar with Mongolian culture than other doctors. The fourth reason was an inspiring book. One day, Park received a book titled Leaving written by a famous missionary Yong-kyu Lee as a gift, and as soon as he saw the cover of the book, he was shocked as if he was hit on the head with a hammer (Lee, 2012). Through this book, God seemed to have said, 'Leave' to him who was about to sit down for future problems. However, Park had the situation that he could not leave at once. Because his old-aged mother was ill with cancer. He wished he could leave after seeing his mother's recovery, but he did not know how long it would take. If his mother's problem was solved, there might be another problem. Eventually, however, his whole family, including his mother, decided to leave for Mongolia, knowing that it was a legitimate attitude toward God's call to leave for mission field. This was because he was caught by the desperate sense that if he did not leave now he would never be able to leave in the end. Eventually, Park was ordained and sent as a lay medical missionary from the Protestant Seoul Dream Church in 2014. His wife also became a medical missionary in Mongolia (Choi, 2016).

\section{MNMU Ministry}

His ministry after returning to Mongolia is to take the position of a surgical professor at MNMU, which he had in the past. At this university, Park works closely with his fellow doctors, especially Christian medical staff sent from Korea (C-channel, 2020). Pediatricians Won-gyu Choi and In-su Na, otorhinolaryngology doctor Young-hoon Han, and rehabilitation medicine doctor Yun-kyung Lee are highly respected by Mongolian medical students. Choi has organized the Mongolia Medical Mission and has been meeting with his fellow professors once a week every Friday, sharing prayer topics. The Korean professors are taking time to visit and serve sick residents suffering from financial difficulties in the remote Ulambatar area over the weekend. Usually, patients with gastrointestinal disorders, arthritis, high blood pressure, and diabetes are taken care of for free, and Park is performing surgery on all those who need it.

\section{Agape Christian Hospital (ACH)}

Park had no plans to set up a hospital in Mongolia. Nevertheless, there were several factors he made up his mind to start his hospital ministry. Mongolian patients with vascular disease who had been treated by Park constantly asked him to begin a hospital. In Mongolia's poor medical environment, vascular specialists are not often seen in general hospitals. If he established a hospital specializing in vascular therapy, many patients could be helped, they insisted. When he heard this request often, he thought, building a hospital might be God's will. Yet, in order to set up a hospital, he had to prepare 
the hospital site and building, and it was too difficult for him to handle these problems alone. Happily, one day an inquiry came to him about managing a hospital at the site of Agape Welfare Center (AWC) in Ulaanbaatar. This center was founded by Seoul Hallelujah Church in 2009. It was a multi-purpose building consisted of clinic, kindergarten, and guest houses (No 2012). However, when Elder Sang-don Park, the head of the center, died in November of that year, the center was vacated for five years thereafter. Hallelujah Church's offer to Park to use this building as a hospital solved Park's concerns in an instant. Park was finally able to open ACH on 31 August 2016 with the first letter of the hospital name as "Agape"in order to continue the spirit of AWC. Therefore, $\mathrm{ACH}$ is Mongolia's first Christian hospital created by remodeling AWC.

$\mathrm{ACH}$ is a non-profit hospital operated with the help of Korean churches and voluntary donors. It is located near Ulaanbaatar Chinggiskhan International Airport and provides medical services to many poor people. Some of them come from other hospitals after being diagnosed with no hope of recovery (UBACH 2021). There are two major medical areas where $\mathrm{ACH}$ has the best expertise and best medical facilities in Mongolia. One is the hospice sector, which helps patients who are facing death, and the other is the field of hemodialysis. Park has decided to focus on the two areas first to ensure the identity of the hospital. Currently, $\mathrm{ACH}$ "has more than 10 Korean medical missionaries, seven Mongolian Christian doctors, 30 Mongolian nurses and employees, 10 haemodialysis units, Xrays, ultrasound, endoscopes and electrocardiograms. Outpatient departments consist of internal medicine, surgery, pediatrics and gynecology" (UBACH, 2021).

\section{Medical Services in Marginalized Areas}

Park has been visiting villages in the medical blind spot in Mongolia more than 10 times a year to provide medical services. It is said that when Dr.
Park sees sick persons, the pain of those persons first comes into his eyes. As these suffering common people are scattered in Mongolia, he is making time for medical service trips. Due to the nature of Mongolia, which is largely uninhabited country, Park and his coworkers often run day and night to visit a village. They are on a difficult journey across the thick snowy roads and frozen lakes, literally crossing mountains and waters. Even after such a hard arrival, they eagerly treat patients in poor environments with portable X-rays, ultrasound and even a generator. As we have seen, his medical missionary began with his friend's will, but now he expresses that this service is very wonderful beyond imagination (Kim 2020). Real joy and happiness are not about controlling people and enjoying money and power. It may be true that genuine freedom and happiness come from a lowly place where we love and serve the poor and needy. Following the healing ministry of Jesus, Dr. Park does his best in caring his patients with all his heart. Of course, Park's treatment method is different from that of Jesus. Unlike Jesus, he does not cure diseases by casting out evil spirits (Luke 4:31-37) or creating miracles (John 2: 1-11). This is because he treats diseases based on rational medical science. However, he exactly follows Jesus' method in the spirit of healing. Jesus' motivation for treating patients was that diseases are spiritual and physical forces that drive humans to various sufferings. These forces deprive humans of their own identity. Disease causes one to lose abundant companionship in the family; it breaks and destroys all the relationships one should enjoy in the social community. Therefore, the sick should be cured and enjoy happiness at home and in society. Jesus and Park are not on a different path in terms of returning to normal daily life and restoring relationships with other social communities.

\section{Park's Mission Theology}

Mongolia enacted the National and Religious Corporation Relations Act on November 11, 1993. 
According to Article 3 of this Law, all Mongolian citizens have freedom of faith. However, Article 7 clearly states that any religion "forbids the force of thoughts against people who do not believe in religion, the exercise of pressure, incentives through money, deception, damage to health and ethics, and causing mental confusion" (Mongolro 2006). Therefore, all evangelical acts that appear to be forced are considered illegal before each individual accepts Christianity on their own. Park realizes that he must do the Gospel ministry very wisely under the Mongolian religious policy, refraining from direct evangelism and conducting indirect relationship evangelism. This does not mean that he has forgotten his missionary position.

\section{Park's Concept of Mission}

Park learned that there was a problem with his previous missionary work in Mongolia for four years. He thought that missions were heavy, scary and difficult, and only special people could do it, but he concluded that lay people like him would do it. In addition, it is argued that one not only goes to the mission field as a missionary, but also live a missionary life even if one does not go to the mission field. The missionary life he refers to is a life in which all Christians recognize that Christ is the master in one's daily life (Park 2016). In this sense, mission can be done as much as possible while living in one's own country without going to the foreign field. Therefore, mission is said to be the most enjoyable and glorious work for both the "front" mission in the actual foreign land or the "home" mission living in one's own country in so far as one is living with the heart of Christ (Park 2012).

Then what is the "Christ's heart"? To this question, he explained his own experience as an example (Park 2016). Once Park did his best to help a Mongolian patient, who later sued him and waged a court battle for a huge sum of money. At times, Mongolian gangsters under the patient's direction came to Park's home, beating Park, and intimidating Park's family. It was difficult to welcome these Mongolians as friends. Because Park had never hit anyone in his life, nor had he ever been beaten by anyone. Over time, however, Park realized that he was living under the illusion of a philanthropist. He found that he did not love them with the heart of Christ (Park, 2016). The change in his inner self came when he remembered the Gospel of Matthew 25: 40, which says "Truly I tell you, whatever you did for one of the least of these brothers and sisters of mine, you did for me" (NIV). The "one of the least" here includes all the marginalized, the poor, the lonely, the sick and the vulnerable. The mind of the gangsters and the accuser who came out rough to him were sick. They seemed to be strong on the outside, but they were weak and fearful in their spirit. The message of the Matthew's Gospel made Park think, "How difficult it was to approach you [Park] in this way?" On the other hand, God seemed to ask him, "Do you really love Mongolians?". Through this experience, Park sensed that he did not love "the one of the least" or "the extremely small person" with the heart of Christ. He had been self-justifying himself by blaming various plausible reasons and circumstances. However, this justification was not the Christian way of life. For Park, the mission God wants is to see people with Christ's eyes, feel their pain sincerely, and respond with compassion and true sympathy.

\section{A Method of Fruitful Evangelism}

Park recognizes mission methods such as direct evangelism and discipleship programs for the spread of Christianity. However, considering the religious policy of Mongolia, he believes that a more flexible and indirect evangelism are needed than direct evangelism, which is seen as forced religious activities. He calls for relationship evangelism, avoiding aggressive evangelism, which is often carried out using so-called management strategies or artificial means. Park has demonstrated the relational evangelism by showing two examples. 
One is the ministry of the Tssatan tribe. Since 2002, Park's medical service team has been visiting these people. On his first visit, Park performed several surgeries in their triangular tents. Out of curiosity, these people flocked around to watch him. When the patients were cured, some of them articulated: "Dr. Park is a god." Park felt the need to enlighten them by explaining that he was not a god. He was able to calm their surprises and questions by speaking naturally about his Christian faith. For a long time, the villagers thought that they were cursed by evil ghosts when they got sick, so they visited shamans. Now they know that when they sick, they must go to able doctors, not the village shamans. The following year, when Park visited them, he found that some of them had already become Christians and read the Bible.

One other example of relational evangelism is naturally occurring in $\mathrm{ACH}$. Certain Mongolian patients spend the last hours of their lives at $\mathrm{ACH}$. The hospice ward of $\mathrm{ACH}$ has patients on the verge of death. These patients have lived dreaming of the great possibility of achieving something when they are young and healthy. However, their present lives are faced with an unknown fear of death. At the end of their lives, their greatness and dwarfism are dialectically confused in their consciousness. At this time, Christian messages (John 3:16, I Cor.15:26, etc.) can exert great power to comfort them so that they are able to die peacefully. Even in the dialysis ward, relationship evangelism occurs smoothly with patients. Dialysis time to exchange blood takes almost four hours, and patients receiving dialysis visit the hospital about three times a week. Park thought it would be nice to tell interesting songs or stories to patients who had to lie down doing nothing for such a long time. Thus, he decided to give patients a chance to listen to hymns and Bible stories. Of course, such listening is possible only when the patients give their consent. This is because it follows Park's mission principle that he will not preach the Gospel through any forced means. Many Mongolian patients in $\mathrm{ACH}$ have confessed their faith, saying, "God has built this good hospital, and I thank God and the hospital staff" (UBACH, 2021).

There is a motivation for Park to strongly conduct relationship evangelism, which is an indirect mission work. $\mathrm{He}$ has clarified his "theology of relational evangelism" in his sermon, "Digging a Well with the Cross" (Park 2019). The sermon seems to indicate that there are two factors which people instinctively crave beyond culture, gender, age and occupation. One is a sense of belonging and the other is pure love. The human is not an animal that exists by chance alone. Being born is not a coincidence, but at least by the body of a mother. Generally speaking, one comes into the world through one's parents' bodies and spend time with them until one reaches a certain age when one is called an adult. During the time of growth, if one has brothers and sisters, one will have relationships with them. These relationships are more clearly manifested in the home, the smallest unit of society. If members of a family through diverse relationships do not feel any threat, they will feel a sense of belonging to their family. However, the relationships with them are not fully filled by mere sense of belonging. Although they belong to a family but feel that they are not loved, they are not happy to spend time with them. This is because they share only superficial relationships with one another. For Park, they have failed to create a deep companionship. To solve this life problem, Park answers that the humans need to eat "eternal food" to taste true love (John 6:29).

How can we eat the eternal food? Park theologically responds to this question by saying that we must establish a one-to-one personal relationship with the transcendent God. This is the vertical order between God and the human. When the humans have the personal relationship with God, the true source of life, they can obtain all kinds of spiritual nourishment from God. Once this process is established, the humans can horizontally unite with their fellow humans and nature around them. 
In other words, the mystery of the cross, where vertical and horizontal meet, solves the problems of belonging and love that we humans so long for. Here we can realize that the cross-as Park refers to-is not a miracle-working material of idolatry. If the cross is understood as a source of reification that satisfies one's religious passion, it will no longer function as a spiritual guide. In connection to this, Park has emphasized that one must stand before God, who is the essence of truth, goodness, and beauty, accepting the spiritual meaning of the cross. This truth instructs that human goodness and love are actually indirect entities that come from God.

For Park, therefore, the method of missionary work should be done as an agent of God, not as the master. Some Christian leaders make mistakes with pride, boasting that they build many churches and gather numerous saints by conducting aggressive evangelistic works with their strength and ability. This kind of "success" story is in fact religious imperialism in the guise of missionary work. A wise evangelism for him is an indirect religious service based on proper human relationship in which God's love does look like the scent of flowers, penetrating quietly in the heart of people. When God's life as a living water is overflowing, Park positively believes that people voluntarily come to drink it. As will be seen, his future vision-the establishment of a general hospital and medical school in Mongoliaseems to be a process that illustrates this stream of life.

\section{PARK'S SPIRITUALITY}

\section{His Humility}

As a religious person, Park seeks spirituality, the highest and most essential part of human life that may be realized through achieving true selftranscendence. For him, this spiritual reality is vivid and therefore can be tasted as he makes a personal relationship with the transcendental reference, namely his Christian God. Yet the course to interact with this God is not much complicated. He prays at home every day and meditates on the Bible. When he arrives at the hospital in the morning, he gets together with all the staff to worship and go to work. At the worship service, he preaches hotly and praises joyfully. His sermons and lectures are clear for ordinary people to understand. His life is also not hidden in any mysterious way. His work of $\mathrm{ACH}$ and his family life are almost always open to the public. When he shares the Bible with other Christians, he carries out the position of an evangelist. In medical school, he teaches medicine as a teacher. He works as a physician when looking after patients. He seems to be repeating the first century Jesus' three important works in the NT: preaching, lecturing and healing. According to the NT, Jesus' behavior is exceptionally and radically refreshing. He shows a life different from highranking religious leaders and outstanding scholars of his time. Jesus does not exude a great religious smell; as a friend of the marginalized, Jesus shows the world the mystery of the kingdom of God. This mystery is the mandate: love one another (John 13: 35). In many senses, Park deserves to be proud of his education or career, but he does not do this. He imitates his teacher, Jesus, by humbly living a life of service to the Mongolians. Of course, he is not perfect, so he makes mistakes sometimes. Yet he does not try to conceal such mistakes, thereby earning trust and respect from many people.

\section{A Lay Leader Who Breaks the Dualism of Holiness and Vulgarity}

Many people long for a transcendent and ultimate reality that cannot be touched by their emotions and reason. In order to achieve perfect union with this reality, they choose for themselves the special training of the religion of their choice. Their efforts and training to find and match the deeper spiritual world are all prized in societies that allow religious freedom. In this respect, many higher religious leaders abandon marriage on their own and pursue a holy spiritual path by capitalizing in quiet temples or monasteries. In most cases, the reason they aim 
for this kind of lifestyle is that the closer they are to the world, the more they are stained with the sin of greed, which hinders their spiritual development. However, Park is walking the opposite path with these religious trends. Like most families, he struggles with small and big family problems. He has to endure young medical students who are not yet fully trained. Patients who want to undergo surgery by borrowing his "golden hand" are always full. When performing surgery, several people work together as a team in the breathtaking tension. In addition, he preaches or gives Christian lectures at the invitations of Korean churches throughout the world. When he visits remote areas in winter season, he stays in the cold of -20 or -30 degrees centigrade and treats his patients. His positions-family head, professor, preacher, hospital director-are all demanding and highly disciplined community leadership. In Korean proverbs, there is a saying that "children grow up on the back of their parents" or "the lower water is clear only when the upper water is clear." These proverbs indicate that a leader in any community should always set an example. The life of such a leader is, in fact, by no means less intense than the training practiced by higher religious monks or priests. It may be easier to maintain spiritual life in a hermitage or monastery apart from the world without taking serious social responsibilities. However, as a lay religious leader, Park is showing a good model that he can break the dualism of holiness and vulgarity.

\section{The Life of "No Possession"}

Here, "no possession" does not mean that he has nothing literally. Park also has the tools of life that most people have. His philosophy of life about no possession can be seen more clearly from his wife's answer: "What are you doing living in abundance? ... What are you doing eating delicious food?" (Jeong, 2018). The average person's desire to maximize ownership is because they want more economic abundance to make food, clothing and shelter comfortable. For this reason, every effort is made to save money. Nonetheless, Park's couple have never saved money for themselves in Mongolia. Due to medical service trips across Mongolia more than 10 times a year and taking care of financially difficult patients for free, there is no time for money to come in. While they were medical students in Korea, Park chose surgery and Jeong chose obstetrics and gynecology as their majors, which medical students avoided the most. They have become specialists in these fields. Surgeons and gynecologists are those who often live with blood to treat their patients with surgical knives. There are many cases in which patients or their families criticize and sue if surgeries go wrong. Despite these unique challenges, surgeons and gynecologists do not make any more money than other medical doctors. Obstetrics and gynecology doctors, in particular, are the lowest income medical doctors in South Korea. This is because young Korean women tend to postpone giving birth or give up motherhood altogether even if they get married. Considering these circumstances, Park and his wife certainly do not choose the path of medical doctors for economic benefit, but a sense of mission to save the lives of those who lead difficult lives.

\section{Outstanding Crisis Management}

Park faced several major crises while working as a missionary in Mongolia. One of them appeared when he did his best to establish Mongolia's first Christian hospital with sincerity and diligence (Park, 2017a). His sending Korean church, seeing his vision, also responded in the best way. The church, which had only been planted for a few years, sent a large offering of about US \$100,000. Many other South Korean churches also participated in offerings across denominations. The hospital remodeling proceeded smoothly, and medical equipment was imported from South Korea. People who would work in the hospital were also recruited and paid monthly. Now, with a permit from the Minister of Health and Sports of Mongolia, the hospital was in hopes of starting ministry. However, 
this important permission was not issued. Park took pictures of the hospital building and sent them to the sponsoring churches, saying that the hospital will open soon, but the hospital opening ceremony was not possible. Park thought there were no defects in all documents regarding the opening of the hospital, but the permit was not issued even after three months, six months, and a year and a half.

While waiting for the permit, weary supporters began to ask Park what had happened. How did he use those big offerings? Did Park use it personally? These questions brought him tremendous mental pressures. He could tolerate other things, but he was desperate for this moral doubt. The reason he waited for the hospital permit for a long time is that he wanted to open a clean and honest hospital. Although he was informed that he should lobby Mongolian government agencies to attain the permit, he refused such cheating because he absolutely did not want to be a false religious person. As a result, a terrible misunderstanding occurred, reaching a point where he could not stand. Finally, he thought about lobbying people as a kind of necessary evil in order to quickly clear the misunderstandings of his patrons. Thus, Park prepared some money to meet a responsible Mongolian Minister, who was arrested on charges of bribery even before Park carried his plan (Qyundari, 2015).

Unexpectedly, Park had to stop lobbying. This incident has established itself as an unforgettable spiritual lesson to overcome life crises. As a Christian, he learned how foolish it was to fail to trust God and to act on his false passions, ambitions and worries. Even after that incident, the position of the Minister of Health and Sports of Mongolia was not appointed for eight months. Park had to endure all these hard times. The Mongolian government finally decided to grant the permit for $\mathrm{ACH}$. For Park, it was an irresistible pain to receive distrust and misunderstanding from many people. Yet, putting up with this patiently and silently and maintaining an honest life by believing in the justice of God have become the principle of crisis management for him ever since. The second crisis Park talks about is the temptation of honor. Although the desire for honor or power may differ slightly for each individual, the temptation of it comes to all people. When Park achieved a considerable success in his medical mission, he began to think that he was showing at least a very appropriate model of current mission (Park, 2017a). At this time, Park suddenly remembered that how feeble he was when he met hardships in the course of attaining the permit of $\mathrm{ACH}$. He recalled that in that period of suffering he was a fragile human who could not do anything. Furthermore, he came to realize that God was not using him without thoroughly destroying such desire as honor seeking. Currently he is reminded every day that ACH is God's and therefore he is nothing but a servant who serves this hospital. In fact, the main basis of this hospital was founded by Elder Sang-don of Hallalluya Church and Park is only the successor, inheriting the noble will of Elder Sang-don (Park 2018). Park has interpreted his position as Joshua in the Old Testament. As if Moses completed the Exodus and handed over the leadership to Joshua, Elder Sang-don finished all preparations for $\mathrm{ACH}$ and entrusted $\mathrm{ACH}$ management to Park. Park needs only to do well as Joshua's role. In the future, the hospital may become bigger and perhaps continue to do great things, but the fruit of all the ministry in this hospital is God's and no one including himself. Since the king of this hospital is God, Park must work only until God has entrusted him and then withdraw (Park, 2017a). In short, Park has diagnosed that one can no longer grow when one achieves a small thing and is intoxicated with it. Such a person is no different from building a small castle and living in it as a lord. The lord in his castle begins to formulate his self-righteousness and arrogance that can easily magnify his life that he is always right and others are always wrong. The 
selfish desire to be the lord of one castle is the greatest enemy of everyone, Park concludes.

\section{PARK'S FUTURE VISION IN MONGOLIA}

Park intends to establish a general hospital and medical school in Mongolia as his future ministry. For this he bought a large site, which is now a small distance away from the hospital, but close to the Mongolian International Airport. The reason he has this vision is because he wants to provide medical assistance to North Koreans adjacent to Mongolia and people in Central Asia in addition to providing more diverse medical services to Mongolians. Park's medical concern for North Koreans is significant. North Korea, which has shared one language and culture with the same people for thousands of years, split with South Korea and became a communist country after World War II ended. Over the next 70 years, North Korea has become one of the poorest countries in the world. The North Koreans are also groaning in the blind spots of human rights and suffering from numerous diseases such as tuberculosis. Someone who is not politically related to the North Korean regime is obliged to help them. Fortunately, Mongolia has diplomatic relations with North Korea, so mutual exchanges are possible. As Park dreams, if a general hospital were built, it would be possible to provide diverse medical services to the North Koreans in various ways.

\section{CONCLUSION}

The medical Hallyu in Mongolia can be summarized as one word: service. The South Korean medical staff are making every effort to eradicate diseases of Mongolians without taking self-interest. They are contributing greatly to the development of medical care by distributing modern advanced medical practice to Mongolia. They are quietly acting civilian diplomacy praised by most Mongolians. Park is certainly one of the most influential and fruitful South Korean missionaries in Mongolia. He is not a clergy missionary, yet he has presented the model of a professional lay missionary who can do meaningful work without falling behind the clergy. Like his teacher Jesus, he faithfully follows the teachings of the NT by taking the three jobs: preacher, teacher, and physician. Park respects Mongolia's religious laws and conducts indirect evangelism rather than militaristic missionary work, establishing a smooth relationship with the Mongolian government and society. He performed the first laparoscopic surgery in Mongolia, saving countless lives. Amazed by his prowess as an excellent surgeon, Mongolian patients praise him as having the "Hand of God" or" Hand of Gold." As medical services in Mongolia are still not developed, Park is planning to establish a general hospital and a medical school to help more patients. If this work goes as he hopes, not only Mongolians but also people from North Korea and other central Asian countries will be expected to receive considerable help.

\section{REFERENCES}

[1] C-channel. (2020). "Meeting Six Medical Missionaries." Aired on October 5.

[2] Choi, Yeong-gyeong. (2016). "A Man who Loved Mongolia." Kookmin Daily Press on November 29.

[3] Delgermurun, Altangerel. (2007). "Mongolian Doctor to Spread Korean Medical Technology." Korea Times on June 18.

[4] Ha, Seong-hwan. (2019). "Mongolian

Schweitzer, anti-Japanese warrior Lee Tae-

jun." Retrieved from

http://www.hanion.co.kr/news/replyView.htm l?idxno=9104

[5] Jeong, Soo-kyung. (2018). "Little Big Heroes: 22nd Year Doctors and Couples' Philosophy," Aired through TVn on March 12.

[6] Kim, Sin-ui. (2020). "A Doctor who went to Mongolia, Park Kwan-tae.” Christian Today 
on January 3. Retrieved from https://www.christiantoday.co.kr/news/3279

06

[7] Lee, Yong-gyu. (2012). Departure. Seoul: Kyujang Publishing Company.

[8] Mongolro. (2010). "[Mongolia] State and Religious Laws." Retrieved from https://mongolro.tistory.com/646

[9] No, Kyeong-ae. (2012). "Until Hallelujah Church in Mongolia is established."

Retrieved from https://blog.naver.com/sbdavidkim/1501539 20109

[10] Park, Kwan-tae. (2012). "We are the hands of God." Aired through C-Story on April 26.

[11] Park, Kwan-tae. (2016). "The Call to Missionary Life." Preached at Hansung Church on June 26.

[12] Park, Kwan-tae. (2017a). "God's Hand Leading Me." Aired through CTS on February 3.

[13] Park, Kwan-tae. (2017b). "Union-Called to One." Preached at Manna Church on July 30.

[14] Park, Kwan-tae. (2018). "Sweet-rain like people." Aired through Danbi TV on July 7.

[15] Park, Kwan-tae. (2019). "Digging a Well with the Cross." Preached at Manna Church on May 26.

[16] Qyundari, E. (2015). "Health Minister Submits a Resignation Request Following his Arrest." The UBPost on 8 November.

[17] Son, Seong-jin (2020). "Lee Tae-jun, A 'Godly' Physician Who Helped the Independence Movement by Practicing Modern Medicine in Mongolia." Seoul Press on August 11.

[18] TVn. (2018). "Surgeon Park Kwan-tae, who loved Mongolia." Aired through TVn on March 17

[19] UBACH. (2021). "Who We Are." UBACH Homepage. Retrieved from http://ubach.org/who-we-are/ 